\title{
Introducing a Task Management Tool into the Operation of a Management Consulting Firm
}

\author{
A. J. TARJÁNi ${ }^{1}$, N. KALLÓ ${ }^{2}$, B. PATAKI ${ }^{3}$ \\ ${ }^{1}$ Budapest University of Technology and Economics, Faculty of Economic and Social Sciences, Department of \\ Management and Business Economics, tarjani.janka@gtk.bme.hu \\ ${ }^{2}$ Budapest University of Technology and Economics, Faculty of Economic and Social Sciences, Department of \\ Management and Business Economics \\ ${ }^{3}$ Budapest University of Technology and Economics, Faculty of Economic and Social Sciences, Department of \\ Management and Business Economics
}

Abstract. Lean and agile methods are now widely used in various fields. Seeing their success, management consultancy firms also want to take advantage of using them. In this case study, the company selects the appropriate task management tool for their operation, the kanban board, and implements it. The implementation process is supported by quantitative analysis. In order to track the introduction progress of the kanban board, a key performance index is defined: the board activity, which is the number of operations performed on the board in a given time period. Based on the evaluation of over 26 weeks' data, board activity proved to be an appropriate indicator of the kanban board's reception, operation, and stability but the examined individual indicators were not found to be suitable for performance appraisal.

Keywords: task management, lean management, lean thinking, agile tools, kanban board

\section{Introduction}

One of the most important characteristics of service companies is their special types of expenditure and revenue. Expenditures in production always include raw material costs, operating costs, and labour costs. In services, labour costs are significantly higher than raw material costs and operating costs. In the service sector, the most significant expenditure is labour costs; therefore, it is important to manage this resource properly as well. Banks, insurance companies, telecommunications companies, hospitals, and government agencies recognized the importance of task management and want to benefit from new waste-reducing lean methods.

The company in this case study is a small business providing consulting services in general management and value engineering by two senior consultants and one junior consultant. In the case of a management consulting firm (as for the earlier mentioned services), labour costs are the most significant expenditures due to the employees' expertise; thus, it is vital to monitor processes and tasks to increase the portion of value-adding activities. Continuous development is important for the owners, and the monitoring of new techniques and management methods is a regular activity. Choosing a suitable process monitoring and task management tool for this company was preceded by research on possible 
tools and applications. Thanks to the popularity of kanban boards among lean and agile tools, they have piqued the owners' interest. The owners decided to implement a kanban board and manage tasks with it to enhance productivity and transparency. In our research, based on quantitative data, we will show that it seems to be a suitable tool to achieve the earlier objectives and a solution to the company's task assignment and tracking difficulties as well.

\section{Lean office}

Lean philosophy and its tools are based on the Toyota Production System (TPS) and are now widely used by production and service companies as well to improve their processes [1]. Applying productionoriginated tools in a service environment requires a flexible and open approach. Similarly to production, the application of lean methods in office processes aims to increase performance by reducing waste with continuous improvement and respecting people. In office processes, however, we encounter different processes, waste, environmental characteristics, and metrics than those of production.

Applying lean tools in services is difficult because the lean methodology was originally developed for production where there are sequential processes with clear work instructions. However, there are several fields and ways to apply lean principles outside of production [2], and in the second big wave of lean, the focus is on services (education, I.T., health), which provide $50-80 \%$ of jobs in the West [3]. Accordingly, lean office, a concept for applying lean principles in an administrative environment, evolved [4].

The lean concepts valid for production processes are hard to define in a service environment. An office is characterized by unique circumstances described by the Relational Office Model [5]. In an office process, the main input is not always clearly defined at the beginning. The previous process does not necessarily have output requirements or any history at all, and the process rarely has exact output requirements. Employees often do not have clear work instructions and need to gather the necessary information from multiple locations, which makes the real workload of employees less visible. This also implies that employees have more direct relationships with (internal) customers and emphasizes the importance of individual characteristics of employees, which is a positive feature of the services in terms of lean principles. However, intense contact also has setbacks, issues can arise during work, and external noises can interfere with the daily routine. In the end, an output with well-defined requirements must be delivered to the customer.

The systematic search for waste is a challenging task of lean office implementation because it has to be applied at a much more abstract level than in the field of production. Danielsson [3] identified two possible ways to implement a lean office. These are the neo-taylorist and team-centred approaches. The neo-taylorist approach is based on a scientific management approach, characterized by a less humancentred and well-regulated system, with standardization at its core. The team-centred approach is more human-centred, focusing on problem-solving and building a learning organization, which is more favourable for a family business. Both systems are designed to reduce lead times and waste.

The usual types of waste can also be found in the administrative field, and they can also be grouped according to whether they are work-related waste or managerial waste [4]. The typical waste categories and examples in the firm are shown in Table 1. 


\begin{tabular}{|c|c|}
\hline Traditional waste categories & Example from the firm \\
\hline Waste of transportation & $\begin{array}{ll}\text { - } & \text { Delivery delays } \\
\text { - } & \text { Moving files } \\
\text { - } & \text { Unnecessary e-mail attachments }\end{array}$ \\
\hline Waste of inventory & $\begin{array}{ll}\text { - } & \text { Procrastinated tasks } \\
\text { - } & \text { Forgotten tasks }\end{array}$ \\
\hline Waste of movement & $\begin{array}{l}\text { - Unplanned layout } \\
\text { - Unnecessary walks } \\
\text { - Searching for documents } \\
\text { - Searching for information }\end{array}$ \\
\hline Waste of waiting & $\begin{array}{l}\text { - Waiting for approval } \\
\text { - Information waiting to be processed }\end{array}$ \\
\hline Waste of overproduction & $\begin{array}{l}\text { - Providing unnecessary service } \\
\text { - Providing unnecessary information } \\
\text { - Duplication } \\
\text { - Unnecessary printing }\end{array}$ \\
\hline Waste of overprocessing & $\begin{array}{l}\text { - Unnecessary paperwork } \\
\text { - } \quad \text { Lack of standardized processes }\end{array}$ \\
\hline Waste of defects & $\begin{array}{ll}\text { - } & \text { Checking for errors } \\
\text { - } & \text { Correcting errors } \\
\text { - } & \text { Unclear communication }\end{array}$ \\
\hline
\end{tabular}

Table 1. Waste categories of the consultancy environment

In addition to the traditional types of waste shown in Table 1, it is common in the lean office to interpret other types of waste, for example, waste due to interruption, waste of information and time due to poor communication, and additional expenditure due to I.T. systems. Due to the similarities presented in Table 1, lean tools such as value stream mapping, various problem-solving and root-exploration methods, 5S, and poka-yoke solutions can also be used effectively in a service environment [6].

Despite the difficulties, there are more and more application examples to implement lean office where there is no physical product at all. Such areas include quoting, sales, accounting, and H.R. [7]. Hadid and Mansouri [8] prepared a report on services published in the literature. Their results show that most of the implementations are in healthcare, office operations, civil sector, and education, followed closely by logistics, I.T., and banking sectors, and some examples can be found in call centres, telecommunications, consulting, real estate, and the hospitality sectors. Implementation of lean and agile tools require increased administration and discussion, which needs continuous effort. Szabó and Ribényi [9] investigated the application of agile tools derived from lean principles (scrum, kanban, and eXtreme Programming). 95.8\% of survey participants linked these three agile methods directly to success. Sustaining the implemented changes in the long term requires the holistic application of lean thinking in the daily contribution of leaders [10]. 


\section{Kanban board}

Kanban method is based on the lean tool known in production systems for inventory monitoring and replenishment [11] and to support the operation of a pull system. Outside of production, kanban boards were first used in software development to define, allocate, and track tasks. With the help of a kanban board, workflows can become visible by dividing the work into several smaller tasks and placing them into separate columns based on their status. The progress of the tasks is symbolized by moving the cards between the columns. For improvement purposes, the kanban board usually has Work In Progress (WIP) limits in some columns and measures the lead time for each task.

Two visually similar other tools are agile dashboards [12] and scrumban [11], and they are used in more complex environments. These tools differ from kanban in the underlying content. Agile characteristics emphasize responsiveness, flexibility, and speed through an iterative and incremental approach defined by the Agile Manifesto [13]. Agile boards and extended agile boards are used in organizations where delivery is constant, production is scheduled in short iterative sprint cycles, and flexibility is key to customer satisfaction. Scrumban and scrum board is a hybrid approach where teams are organized in scrum groups, and workflow is visualized on a kanban board. The transition from predictive to agile operation is continuous, and the application of these tools should be aligned with the organizational goals. The management consultant company considered visualization and workload balancing as the main goals with the new task management system, and the tool applied was chosen to be called a kanban board.

At the beginning of the implementation, the need for an online board was discovered. Tasks can appear in various locations, and team members should be able to capture them with their smart devices. There are several online free and paid applications for this purpose $[14,15]$. The suitability of two of these, Trello and Kanbanchi applications, was examined. The two possible software were compared using a Franklin balance sheet. Results are presented in Tables 2 and 3.

\begin{tabular}{|l|l|}
\hline \multicolumn{1}{|c|}{ PROS } & \multicolumn{1}{c|}{ CONS } \\
\hline Previous personal knowledge & No autosave function \\
WIP limits are available & Not Google based \\
Stickers on cards & No sizable cards \\
Multiple tables are supported & No custom backgrounds \\
Coloured backgrounds & No coloured cards \\
Mobile application & Registration needed \\
Labels on cards & \\
Deadlines on cards & \\
Cards with lists & \\
Cards with files uploaded & \\
Cards can be referred & \\
\hline
\end{tabular}

Table 2. Franklin balance sheet on Trello 


\begin{tabular}{|l|l|}
\hline \multicolumn{1}{|c|}{ PROS } & \multicolumn{1}{c|}{ CONS } \\
\hline WIP limits are available & No previous knowledge \\
Autosave function & No adjustable card sizes \\
Google compatibility & Multiple tables are not supported \\
Coloured cards & Only Google compatibility \\
Custom backgrounds & No mobile application \\
Deadlines on cards & No desktop application \\
Labels on cards & Advertisements \\
No registration needed & \\
Priorities on cards & \\
\hline
\end{tabular}

Table 3. Franklin balance sheet on Kanbanchi

Based on the Franklin balance sheet, the company's kanban table was created in the Trello application because it has more internal benefits, and long-term maintenance is greatly aided by the prior knowledge of the management.

The kanban board in use is shown in Figure 1. Tasks are captured in the first column called TASKS, according to the rules of card writing. After capturing, cards are labelled according to the type of task, then a person in charge is assigned to them, and a deadline is set according to the project plan or programs. The tasks include project-type, recurring, and one-time tasks. For project-type tasks, the cards can be written in advance based on the project plan. For one-time tasks, such as preparing a summary, the task is captured as soon as it appears. These cards are archived after the task is completed. Recurring task cards, for example, monthly, yearly activities, are not archived but are returned to the tasks to be performed with a new date. The current daily tasks are arranged by the automation in the second column TODAY. In the third column, NOW, are the tasks team members are currently working on. The column NOW has a WIP limit of three, which means all three team members are only allowed to work on one task at a time to focus their attention and prevent multitasking. When a task is done, it goes to the fourth DONE column. In the fifth column UNDER SCHEDULING, unscheduled tasks and ideas are collected.

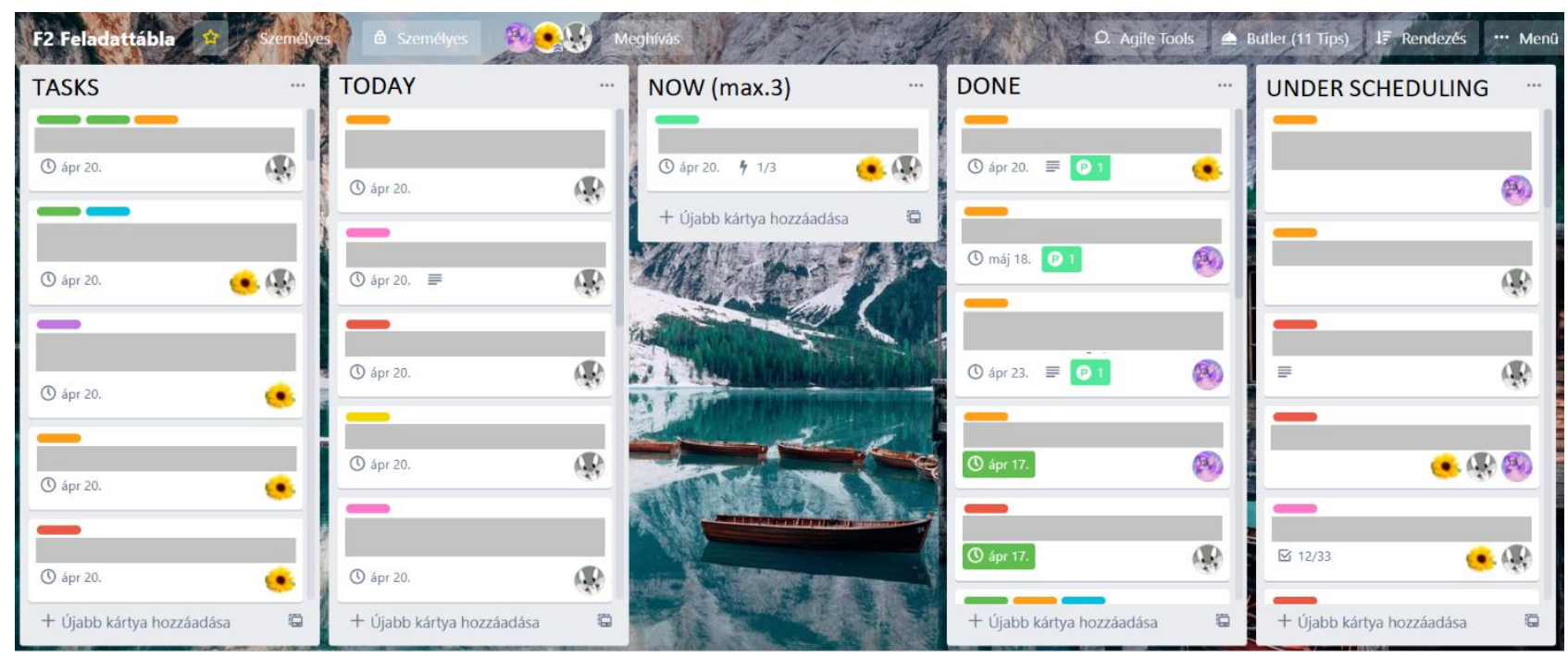

Figure 1. Kanban board in Trello 
Members of the family business are managing their tasks on the kanban board since September 2019. Tasks are allocated and tracked in a simple and transparent way. Lean management usually prefers monitoring the progress of implementation. In the case of the kanban board, results should also be quantified. The kanban board is evaluated according to the data that can be collected from the application's history log. The application creates an entry for each change on the board that can be retrieved and saved for two weeks. An entry shows who made the change, what the change was, and when. The primary numerical indicator of the progress of the implementation is the board activity, which is the number of database entries made in a given time period. This indicator includes all types of activities of all participants.

In addition to the board activity, it is worth examining the data set broken down by types of activities and individuals. From this approach, individual and activity-specific indicators can be formed. During the observed period of six months, the following types of activities occurred on the board: card creation, card moving, card modification (deadline, responsible, description, label), and card archiving. Considered performance indicators are: card creation intensity (the number of cards created in a given time period), card moving intensity (the number of card movements in a given time period), task finishing intensity (the number of tasks finished in a given time period), card lead time (time between the creation of a card and finishing the task), and story points intensity (the number of story points on finished cards in a given time period). These indicators can be interpreted at an individual level as well.

\section{Data analysis}

Quantitative analysis of the implementation phase was based on the data collected by the board's logging function. There were three questions considered:

- (1) If the intensity of table use was different at the beginning (September) and at the end (February),

- (2) If there is a difference in table use between days of the week (Monday and Wednesday),

- (3) And if there was a difference in table use between participants.

These questions resulted in three examined factors:

- (1) month of data collection,

- (2) days of the week, and

- (3) participants.

We recorded all activities in the introductory period. The data processed is from the 26-week period from 28 August 2019 to 24 February 2020. In the quantitative analysis, analysis of variance is used to determine whether there is a statistically significant difference in the intensity of table use at the beginning and end of the introduction period, among the activities of participants, and between the usages on different days of the week. Outliers from the holiday period and times of family issues were excluded from the analysis.

Entries in the board history log include events of creating, moving, modifying, and archiving cards, with the name of the user performing the action and the time of the event. These entries are downloaded regularly and organized in M.S. Excel. Figure 2 shows the number of total entries broken down by days. 


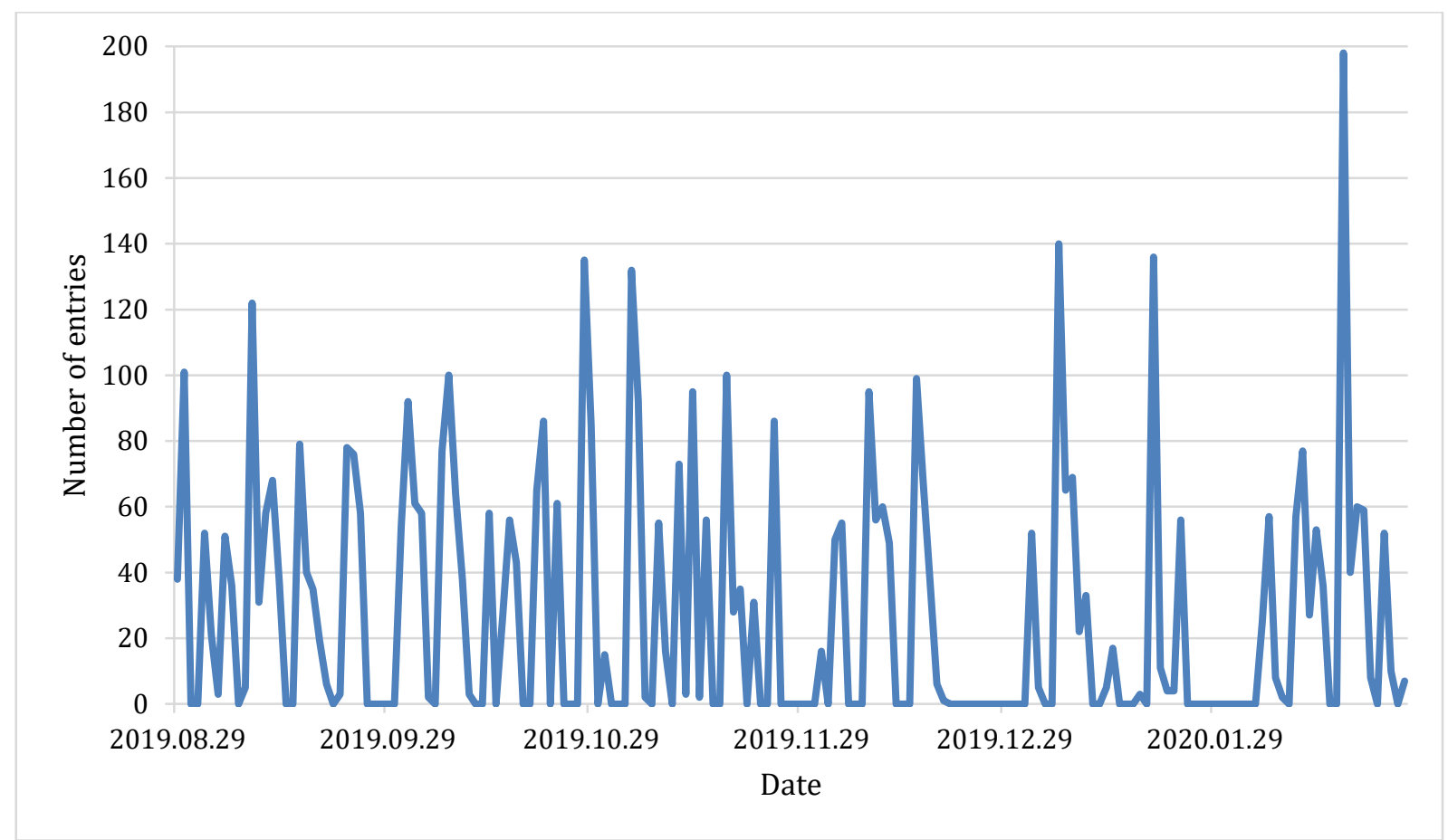

Figure 2. Daily board activity

Each of the analysed three factors (1) month of data collection, (2) days of the week, and (3) participants are discrete and fixed, and interactions between them are assumed. Hypotheses tested:

- (A) Elapsed time has no effect on board activity.

- (B) The day of the week has no effect on board activity.

- (C) Participants have no influence on board activity.

- (D) Interactions between factors have no effect on board activity.

On the number of daily board activities, sudden peaks and subsequent decreasing periods are visible. The peaks on the daily board activity data imply the effect of the day as significant. This phenomenon can be caused by the unique style of using the board. Long-term planning usually happens with setting the card deadlines on Mondays. These are not mandatory deadlines, just reminders when the cards need action. Mandatory deadlines are stored in the card's name. At the beginning of the week, tasks are reviewed and scheduled on the days of the week or occasionally transferred to the next week. The peaks are shown in Figure 2 thus are on Mondays, and the decrease that follows them goes for the rest of the week. Based on the height of Monday's peaks, board activity fluctuated over the examined period. Initial enthusiasm was followed by a small decline in late September, and then in mid-October board activity rose again. In January and February, the board activity showed increased fluctuation. No extraordinary events occurred during this time frame with lower board activity, and the fluctuations may be caused by the stacking of tasks previously scheduled for these weeks or the fluctuations in enthusiasm for the board. Based on the board activity data displayed in Figure 2, a weekly breakdown could smooth the effect of the long-term scheduling practice. Figure 3 shows the board activity by week. 


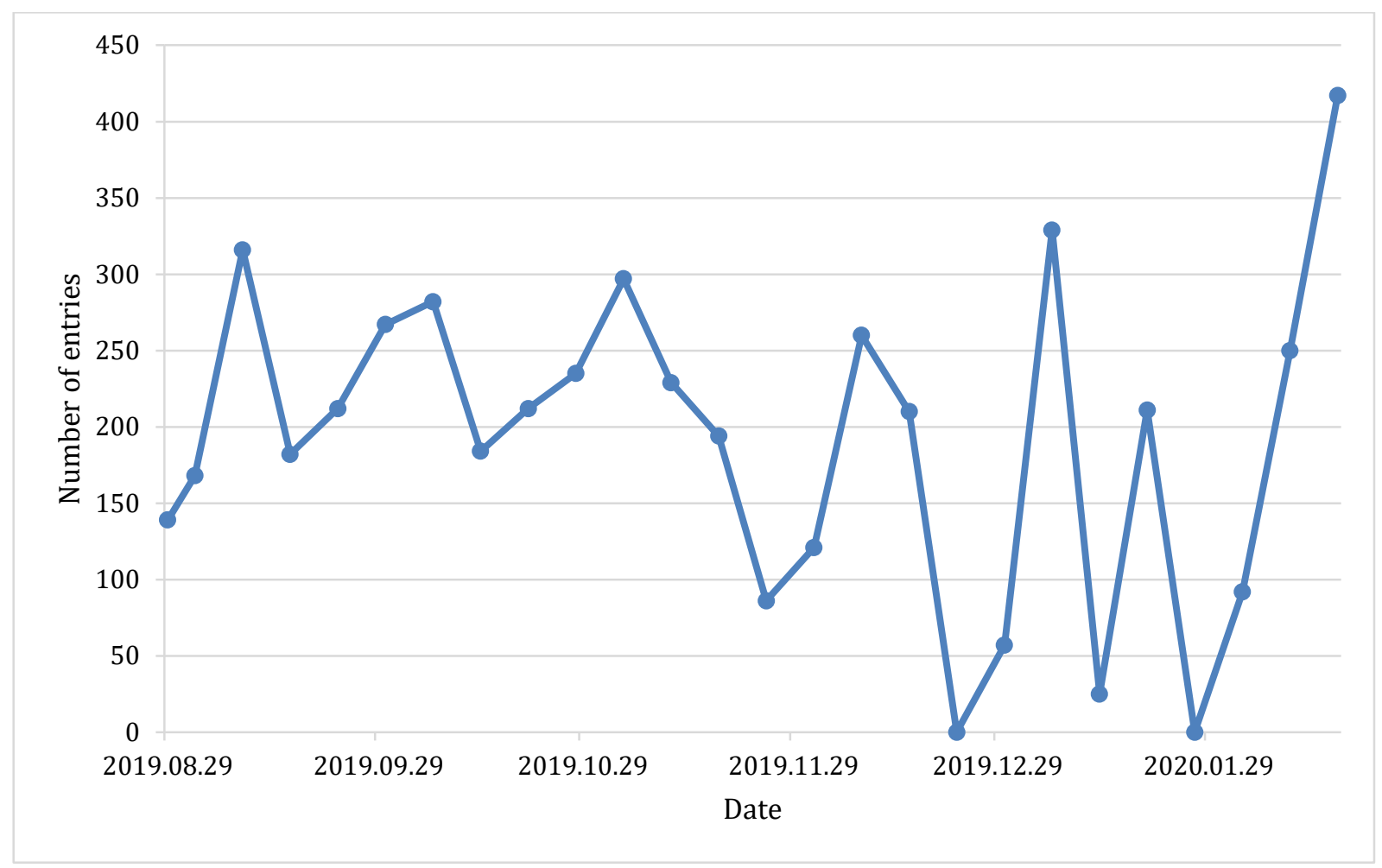

Figure 3. Weekly board activity

The weekly breakdown also shows cycles until mid-November, followed by an unusual decline at the end of November. The waves are not symmetrical; they start with a rapid decline followed by a slow upward phase. The decline begins at the beginning of the month, then increases until the middle of the month and shows a decline again. This fluctuation may be related to mandatory deadlines. Typically, the company works with end-of-month deadlines. When the deadline approaches in the middle of the month, board activity jumps because it becomes increasingly important for everyone to document task statuses and see progress and what is left.

Starting from mid-December holidays and start-of-year busy periods cause sharp fluctuations in the data. At the end of the year, the board activity was around zero because all customers are on holiday. The board activity value below one hundred in the last three weeks of monitoring is also worth not including in the analysis because certain family issues caused this change in the data. Figure 4 shows the board activity in a weekly breakdown without the outliers. The red line represents the average weekly board activity value for the data set. 


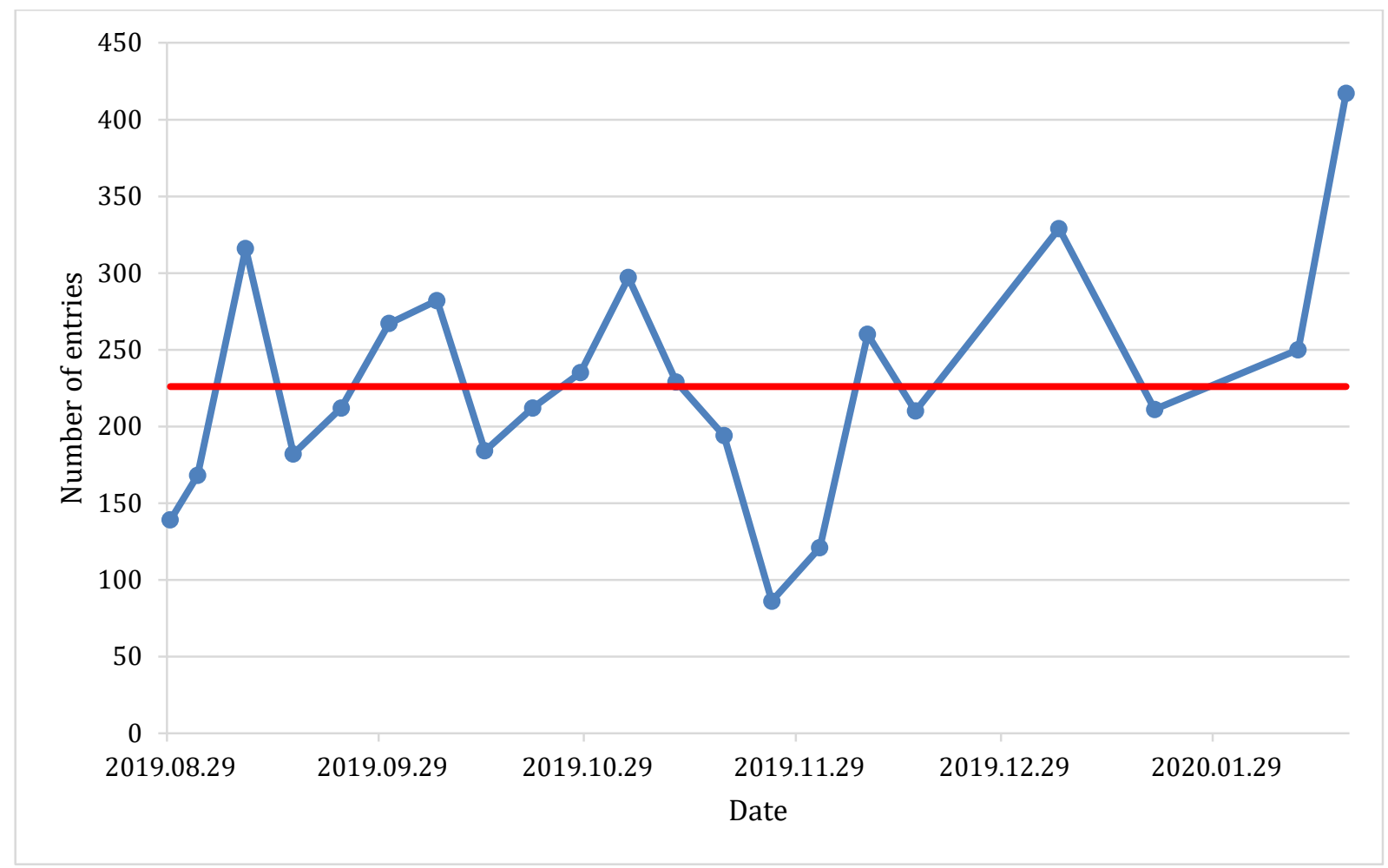

Figure 4. Weekly board activity without outliers

In the previous figures, only the total number of operations has been shown, but the database also allows the analysis of the activity types and individuals. Figure 5 shows the individual board activity without outliers. Participant 2 is responsible for the board and the documentation of the daily meetings and apparently has more entries than the others. The effect of months in Figure 5 has no visible effect.

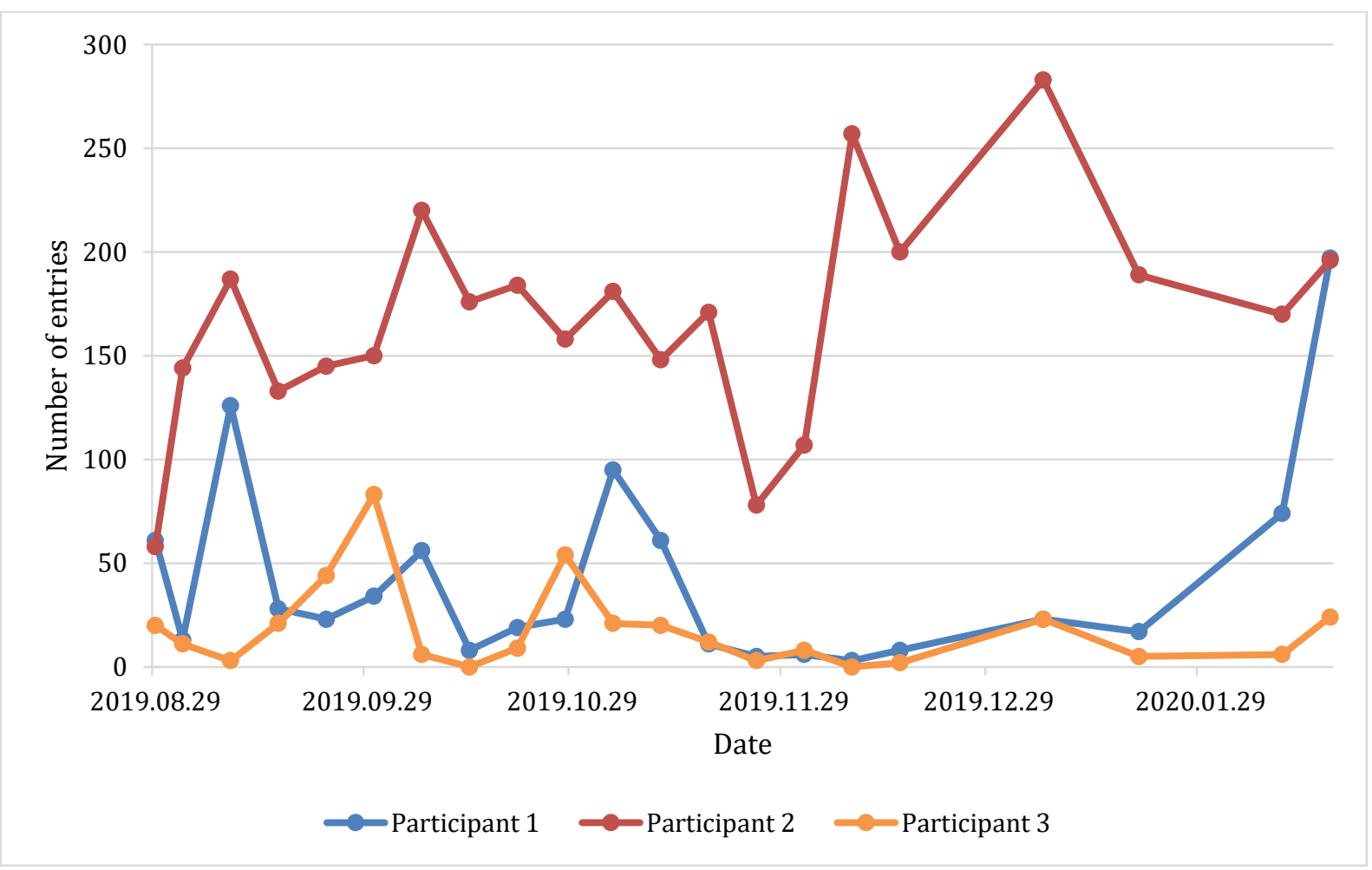

Figure 5. Individual board activity 
Based on Figure 5, the stable period until mid-November is also present on the individual indicator. During this period, the common enthusiasm is evident; participants 1 and 3 also perform actions on the board, not just participant 2. Like the initial stable period, the downturn at the end of November was a common result. The number of board actions for participants 1 and 3 dropped sharply, and only the board owner tried to continue to keep up the pace after some stagnation. With the start of the new year, board activity started rising again, and this growth finally overtook the pre-November period level.

Based on the data, no individual performance evaluation can be performed in this case. Participant 2 has a high level of individual board activities not only because of higher performance but because of the board ownership responsibility and the documentation tasks.

Figure 6 shows the activities in a weekly breakdown without outliers. Of the four observed activity types, two show a higher and more volatile picture, and two show lower and more stable values.

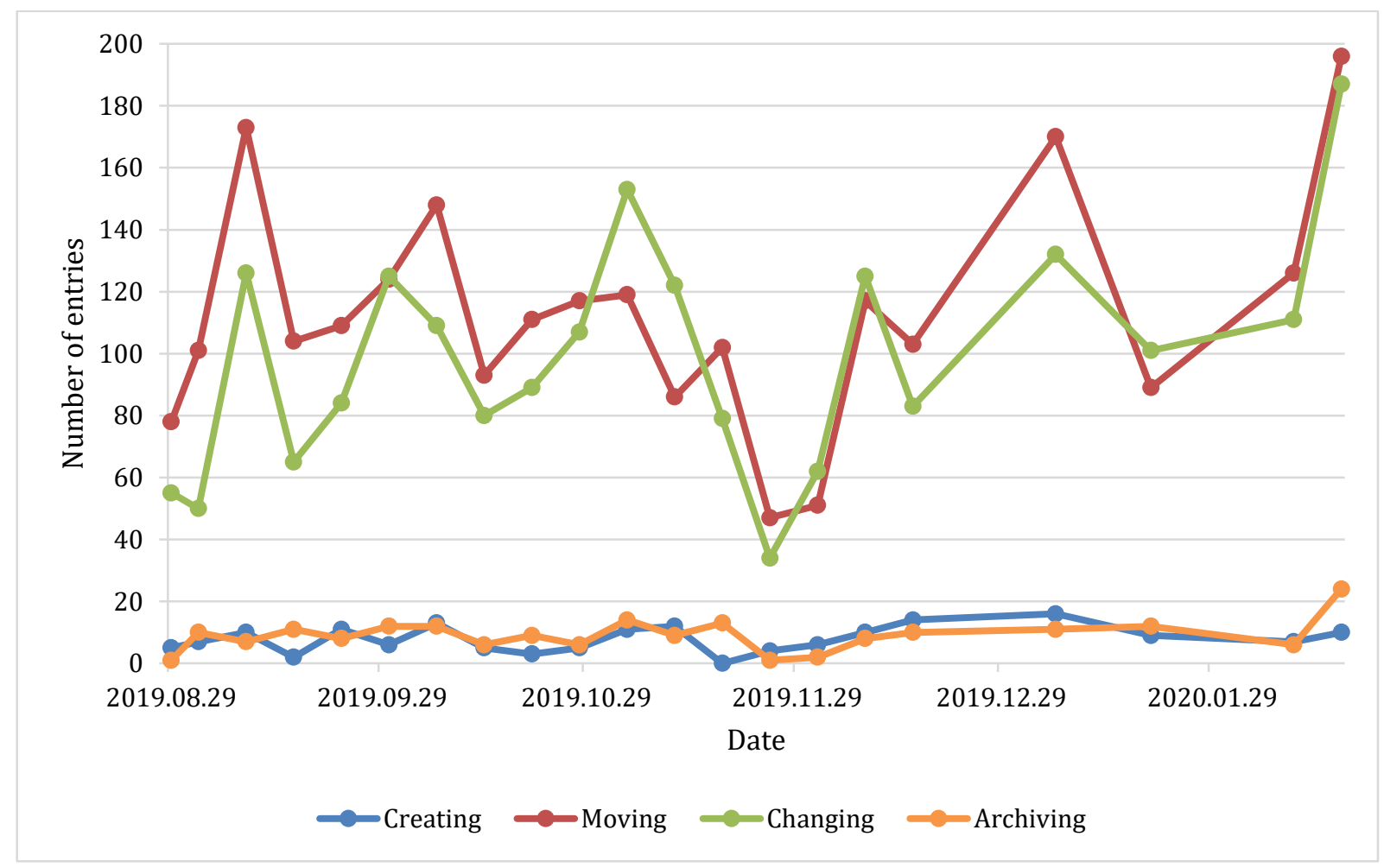

Figure 6. Board activity by activity types

Moving and changing cards are more common events than creating and archiving. There are several reasons for this. A card only needs to be created and archived once but must be moved at least three times before it reaches the finished column if no returning is expected. In addition, there are cards with repetitive tasks that will not be archived because the task will have to be performed next week or the next month, and the team chose not to rewrite them all the time, just change their date and put them back in the TASKS column. There are clearly fewer activities for creating and archiving than there are for moving and changing cards. Creation and archiving show similar values, which implies the balance of the board.

Figure 7 shows the three boxplots for the effect of the three investigated factors. Based on the boxplots, the effect of the days is expected to be significant for the aforementioned reasons. The effect of the 
months is not expected to be significant. The effect of the participants can be significant, as participant 2 is the owner of the kanban board.

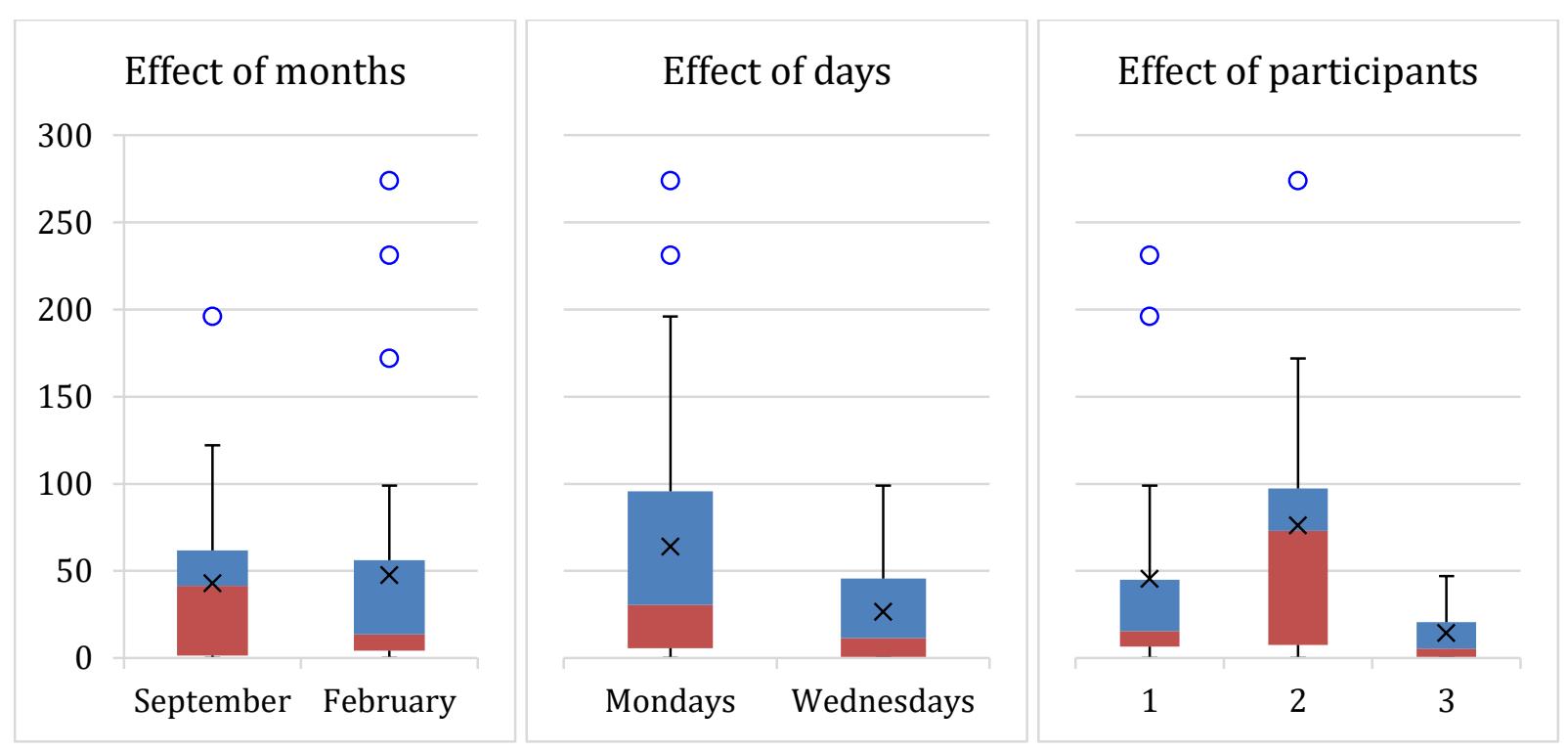

Figure 7. Effects of factors on boxplots

One of the conditions for analysis of variance is that the sample comes from a population of the same variance. Bartlett's test was used to verify this condition. Results of the test are summarized in Table 4 .

\begin{tabular}{|c|c|}
\hline$\alpha$ & 0,05 \\
\hline df_W & 11 \\
\hline B-krit & 19,675 \\
\hline B & 32,842 \\
\hline p & 0,0006 \\
\hline
\end{tabular}

Table 4. Result of Bartlett's test on the original data

Since the value of $p$ is less than the value of $\alpha$, the null hypothesis of the test has to be rejected; the sample doesn't come from a population of homogenous variance. The same result is obtained when using Levene's test. The strength of Levene's test is low for a small sample size, and it still rejects the assumption of homoscedasticity. However, this condition is necessary to perform the analysis of variance. In order to obtain the right conclusions from the analysis, the Box-Cox transform is performed on the original data. Only positive values can be used for the Box-Cox transformation, and each value was modified with one. The value of the $\lambda$ parameter is obtained with the built-in function of the program package, which gives the maximum-loglikelihood estimate of the $\lambda$ parameter. The reperformed Bartlett's test on the transformed data has not been statistically significant (Table 5). The ANOVA test is performed on the new data set. 


\begin{tabular}{|c|c|}
\hline$\alpha$ & 0,05 \\
\hline df_W & 11 \\
\hline B-krit & 19,671 \\
\hline B & 8,660 \\
\hline p & 0,653 \\
\hline
\end{tabular}

Table 5. Result of Bartlett's test on the transformed data

The other two assumptions of the analysis of variance are the independence of errors and normal distribution. The independence of the data is assumed based on the documentation method. The BoxCox transformation on the data implies normal distribution of the transformed values and checked with a QQ plot. After checking the three assumptions, the ANOVA test is performed on the transformed data; the results are shown in Table 6. In Table 6, A stands for the effect of months, B stands for the effect of days, and $\mathrm{C}$ stands for the effect of the individuals.

\begin{tabular}{|l|r|r|r|r|r|r|}
\hline & \multicolumn{1}{|c|}{ SS } & df & MS & \multicolumn{1}{c|}{ F } & p-value & sig. \\
\hline A & 0,227651 & 1 & 0,227651 & 0,047497 & 0,828708 & no \\
\hline B & 11,57805 & 1 & 11,57805 & 2,415637 & 0,128877 & no \\
\hline C & 34,33802 & 2 & 17,16901 & 3,582132 & 0,038125 & yes \\
\hline A x B & 0,275882 & 1 & 0,275882 & 0,05756 & 0,811756 & no \\
\hline A x C & 8,606168 & 2 & 4,303084 & 0,897793 & 0,416395 & no \\
\hline B x C & 6,077384 & 2 & 3,038692 & 0,633991 & 0,536289 & no \\
\hline A x B x C & 1,443895 & 2 & 0,721947 & 0,150627 & 0,860708 & no \\
\hline Within & 172,5465 & 36 & 4,792959 & & & \\
\hline Total & 235,0936 & 47 & 5,001991 & & & \\
\hline
\end{tabular}

Table 6. Result of the ANOVA test for the transformed data $(\alpha=0,05)$

Results of the ANOVA test show that the effect of the individuals is statistically significant, and the other two main effects are not. Contrary to the preliminary assumptions from Figures 2-7, the days of the week have no clear effect on the measured board activity and the effect of the months is not significant at all, which implies the stable operation of the board. The effects of interactions are not statistically significant either. The effect of the individuals is also significant in performing the analysis with the original data set, and the effect of days is significant as well in this case. Therefore, it was worth checking the assumptions and transform the dataset, as it could influence the conclusion. The ANOVA test could be performed on a reduced model where only the main effects are included and none of the interactions. This could further increase the strength of the test if needed.

Based on the results of the quantitative studies, values of board activity are influenced only by the participant of the three examined factors. Preliminary graphical studies predicted the outcome of ANOVA well. The board activity data is not influenced by the days of the week, Monday and Wednesday, neither by the examined months, September and February. Since there was a statistically significant difference in the board activity of participants, the question arises whether these data could be used to 
evaluate individual performance or to estimate team effectiveness. In order to answer these questions, multiple teams and boards are needed, and correlations would have to be found with other financial or production performance indices.

\section{Conclusion}

This paper shared the introduction phase of a kanban board into a management consultancy small business. Progress is tracked with the board activity performance index, and the gathered data is analysed with quantitative methods. Board activity values can be obtained with the board history log that records all board activities. A 26-week examination of the indicator was performed and made it clear that this indicator is not suitable for individual performance evaluation.

Board activity proved to be an appropriate indicator of the kanban board itself. Board activity is an easyto-define, easy-to-understand indicator for measuring the success and operation of the board. Its value should be monitored on a weekly basis, weekly values should be shared, and growth should be rewarded. Continuous development related to the kanban board is expected to flourish and become part of the organizational culture.

Performance indices, however, are not only for assessing the implementation of the new task management system but can also help understand the company's operation and develop a strategy in the long term. Such performance indices can measure performance, support performance appraisal, and suggest customer satisfaction. The performance measurement system must be in line with the strategic goals of the company, and only necessary measurements should be performed [16].

This research has its own limitations. A more extensive analysis (both in the timeframe and sample size) is needed for well-grounded conclusions, and many comprehensive questions could be analysed as well. Is it worth using board activity after the introduction period? Does any other firm use it already? Can it be used for performance evaluation? Can we deduce customer and employee satisfaction from it?

\section{References}

[1] Womack, J.P., Jones, D.T. (2003) 'Lean Thinking: Banish Waste and Create Wealth in Your Corporation'. 2nd Ed. Simon \& Schuster Inc., New York.

[2] da Silva Iris, B., Seraphim Everton, C., Agostinho Oswaldo, L., Lima Junior Orlando, F., Batalha Gilmar, F. (2015) 'Lean office in health organization in the Brazilian Army'. International Journal of Lean Six Sigma, Emerald Group Publishing Limited. 6 (1) pp. 2-16. https://doi.org/10.1108/IJLSS-09-2013-0053

[3] Danielsson, C.B. (2013) 'An explorative review of the Lean office concept'. Journal of Corporate Real Estate, Emerald Group Publishing Limited. 15 (3/4) pp. 167-80. https://doi.org/10.1108/JCRE-02-2013-0007

[4] de Almeida, J.P.L., Galina, S.V.R., Grande, M.M., Brum, D.G. (2017) 'Lean thinking: planning and implementation in the public sector'. International Journal of Lean Six Sigma, Emerald Publishing Limited. 8 (4) pp. 390-410. https://doi.org/10.1108/IJLSS-06-2016-0027 
[5] Rüttimann, B.G., Fischer, U.P., Stöckli, M.T. (2014) 'Leveraging Lean in the office: Lean office needs a novel and differentiated approach'. Journal of Service Science and Management, Scientific Research Publishing Inc. (7) pp. 352-60. https://doi.org/10.3929/ethz-a-010364215

[6] Kelemen, T., Kalló, N. (2020) 'A lean szemlélet eredményes alkalmazása irodai környezetben' [Effective application of the lean approach in an office environment]. Vezetéstudomány-Budapest Management Review, Budapesti Corvinus Egyetem. 51 (ksz.) pp. 59-69. https://doi.org/10.14267/VEZTUD.2020.KSZ.06

[7] Piercy, N., Rich, N. (2009) 'Lean transformation in the pure service environment: the case of the call service centre'. International Journal of Operations \& Production Management, Emerald Group Publishing Limited. 29 (1) pp. 54-76. https://doi.org/10.1108/01443570910925361

[8] Hadid, W., Afshin Mansouri, S. (2014) 'The lean-performance relationship in services: a theoretical model'. International Journal of Operations \& Production Management, Emerald Group Publishing Limited. 34 (6) pp. 750-85. https://doi.org/10.1108/IJOPM-02-2013-0080

[9] Szabó, B., Ribényi, M. (2018) 'Az agilis módszertanok megítélése a beosztottak és vezetők szemszögéből' [Agile methodologies from the perspective of subordinates and managers]. Vezetéstudomány - Budapest Management Review, Corvinus University of Budapest. 49 (6) pp. 22 32. https://doi.org/10.14267/veztud.2018.06.03

[10] Gurabi, A., Mátrai, N. (2018) 'Lean menedzsment evolúciója és a szervezeti tanulás' [Evolution of lean management and organizational learning]. International Journal of Engineering and Management Sciences, 3 (5 SE) pp. 251-9. https://doi.org/10.21791/IJEMS.2018.5.25.

[11] Agile Alliance (2017) 'Agile Practice Guide'. Project Management Institute.

[12] Waldock, B. (2015) 'Being agile in business - Discover faster, smarter, leaner ways to work'. Pearson, Harlow, UK.

[13] Beck, K., Cockburn, A., Jeffries, R., Highsmith, J. (2001) 'The Agile Manifesto'. Agile Alliance [http://agilemanifesto.org, accessed 29 October 2020]

[14] Mishra, A., Mishra, D. (2013) 'Software project management tools: a brief comparative view'. ACM SIGSOFT Software Engineering Notes, ACM New York, NY, USA. 38 (3) pp. 1-4. https://doi.org/10.1145/2464526.2464537

[15] Kashyap, V. (2020) '52 Best Project Management Tools \& Software for 2020 [https://www.proofhub.com/articles/top-project-management-tools-list, accessed 29 October 2020].

[16] Marr, B. (2015) 'Key performance indicators for dummies'. Kindle Ed. John Wiley \& Sons. 